\title{
PENERAPAN CUSTOMER RELATIONSHIP MANAGEMENT (CRM) BERBASIS SMS GATEWAY PADA ONLINE SHOP TOKOFARAH
}

\author{
Arfiani Nur Khusna \\ Teknik Informatika Universitas Ahmad Dahlan \\ JI. Prof. Dr. Soepomo, Janturan, Yogyakarta \\ arfiani.khusna@tif.uad.ac.id
}

\begin{abstract}
SMS applications has become a promising business opportunities in the consumer and industrial markets in the world. One part that can not be separated from the SMS business is the role of an SMS Gateway, a system used by service providers to send and receive SMS automatically. Online shop tokofarah an online web business venture engaged in the production and sales of baby clothes and children. The problems that exist in the online shop tokofarah is the absence of communication between the customer and tokofarah thus reduced customer loyalty, customers are unaware of the latest promos and discounts, so the application of CRM (Customer Relationship Management) is very necessary to help communication. Alternative solutions in addition to implementing CRM also develop and implement SMS technology as a service via SMS Gateway online. Where customers can easily find information on the latest promos and discounts, customers can simply type a certain key word and send it to a specific number that has been provided, the store can also inform customers about the latest promos and products through SMS brodcast. In this study, using Gammu as tools liaison between the device with a computer modem. Making the program using the programming language PHP as an interface, a database maker MySQL tools. The results of the implementation of the concept of SMS Gateway technology is that it can provide convenience for online customers shop tokofarah in knowing the promo and the latest product information and can order via SMS.
\end{abstract}

Keywords: SMS Gateway, CRM, Gammu

\section{Abstrak}

Aplikasi SMS telah menjadi lahan yang menjanjikan untuk meraih peluang bisnis di pasar konsumen maupun industri di dunia. Salah satu bagian yang tidak dapat dipisahkan dari bisnis SMS ini adalah peranan sebuah SMS Gateway, sebuah sistem yang digunakan oleh penyedia jasa untuk mengirim maupun menerima SMS secara otomatis. Online shop tokofarah merupakan usaha bisnis web online yang bergerak di bidang produksi dan penjualan pakaian bayi dan anak. Permasalahan yang ada pada online shop tokofarah adalah tidak adanya komunikasi antara pelanggan dan tokofarah sehingga loyalitas pelanggan berkurang, pelanggan tidak mengetahui promo dan diskon terbaru, sehingga penerapan CRM (Customer Relationship Management) sangat perlu untuk membantu komunikasi. Alternatif pemecahan masalah selain menerapkan CRM juga membangun dan mengimplementasikan teknologi SMS Gateway sebagai layanan via SMS secara online. Dimana pelanggan dapat dengan mudah mendapatkan informasi mengenai promo dan diskon terbaru, pelanggan cukup mengetik key word tertentu dan mengirimnya ke nomor tertentu yang telah disediakan, pihak toko juga dapat menginformasikan ke pelanggan mengenai promo dan produk terbaru melalui SMS brodcast. Pada penelitian ini menggunakan Gammu sebagai tools penghubung antara device modem dengan komputer. Pembuatan program dengan menggunakan bahasa pemprograman PHP sebagai interface, MySQL tools pembuat database. Hasil dari konsep implementasi teknologi SMS Gateway ini adalah dapat memberi kemudahan bagi pelanggan online shop tokofarah dalam mengetahui informasi promo dan produk terbaru serta dapat melakukan pemesanan melalui SMS.

Kata kunci : Sms Gateway, CRM, Gammu 


\section{PENDAHULUAN}

\subsection{Latar Belakang}

Pada saat ini tantangan bagi pelaku bisnis adalah memenuhi kepuasan pelanggan. Tantangan tersebut antara lain seperti mengevaluasi ketersediaan suatu produk, menghasilkan produk bermutu tinggi dan menjamin kualitasnya, memproses produk lebih cepat, memperkirakan biaya yang dibutuhkan dalam proses produksi, meningkatkan sumber daya manusia dengan pelatihan. Pelaku pelaku bisnis yang mengerti dan melaksanakan tantangan tersebut, adalah yang dapat bersaing dan bertahan didunia usaha.

Kemudahan dan kecepatan aliran informasi dalam teknologi informasi dapat menghubungkan satu komunitas ke komunitas yang lainnya. Salah satu produk teknologi informasi adalah telekomunikasi menggunakan handphone. Di dalamnya terdapat sebuah metoda komunikasi yang dinamakan SMS (Short Message Service) yaitu sebuah konsep pengiriman informasi berbasis text. SMS based service ini semakin banyak digunakan oleh banyak perusahaan karena dianggap mampu menjangkau hampir seluruh jaringan pengguna seluler yang menjadi customer perusahaan tersebut dan biayanya yang cukup murah, beberapa perusahaan menggunakan layanan SMS ini untuk meningkatkan optimalisasi pelayanan, dan keperluan komunikasi lainnya. Karena panjang data dari SMS yang bersifat kecil, maka pengolahan data dari layanan ini dapat dilakukan secara cepat sehingga dapat meningkatkan kegiatan bisnis.

CRM merupakan sebuah filosofi bisnis yang menggambarkan suatu strategi penempatan client sebagai pusat proses, aktivitas dan budaya. Konsep ini telah dikenal dan banyak diterapkan untuk meningkatkan pelayanan dan telah menjadi prioritas utama bagi hampir seluruh bidang usaha/organisasi baik berskala kecil maupun besar.

Tokofarah merupakan usaha yang bergerak di bidang penjualan online, transaksi tidak tatap muka melainkan melalui website, Perkembangan usahanya secara perlahan meningkat dari tahun ke tahun. Tokofarah memproduksi barang-barang kebutuhan bayi dan anak. Dengan pelayanan yang baik dan kualitas yang terjamin, pelanggan semakin meningkat dari tahun ke tahun. Selama ini untuk pelayanaan informasi pelanggan masih belum optimal, pelanggan hanya bertransaksi melalui web dan tidak ada pelayanan lebih setelah transaksi selesai sehingga banyak pelanggan yang tidak bertransaksi kembali setelah transaksi pertama selesai, bahkan pelanggan banyak yang tidak mengetahui bentuk promo atau diskon untuk waktu tertentu. Pelanggan juga kesulitan mengakses website untuk bertransaksi ketika sinyal internet tidak memadai, hal ini membuat pelanggan mengeluh atas pelayanan yang diberikan dari tokofarah.

\subsection{Rumusan Masalah}

Bagaimana merancang dan mengimplementasikan CRM Customer Relationship Management) berbasis SMS Gateway pada onlineshop Tokofarah

\subsection{Tujuan}

Tujuan utama dari penelitian ini adalah untuk menghasilkan aplikasi operasional Customer Relationship Management (CRM) berbasis SMS Gateway di onlineshop Tokofarah. Diharapkan sistem ini dapat bermanfaat dan menjadikan sistem informasi yang lebih mudah, cepat dan menjadi informasi yang mendasar untuk pelanggan.

\section{METODE PENELITIAN}

\subsection{Metode Pengembangan Sistem}

Metodologi adalah rincian secara menyeluruh dari siklus pengembangan sistem informasi yang mencakup langkah demi langkah tugas dari masing-masing tahapan, aturan yang harus dijalankan oleh individu dan kelompok dalam melaksanakan tugas, standar kualitas dan pelaksanaan dari masing-masing tugas, teknik-teknik pengembangan yang digunakan untuk masing-masing tugas ini berkaitan dengan teknologi yang digunakan oleh pengembang. Metode yang digunakan dalam perancangan dan pengembangan suatu aplikasi sistem informasi pada umumnya mengacu pada tahapan pengembangan sistem.

\subsection{Tahap-tahap Pengembangan Sistem}

Dalam suatu sistem terdapat beberapa tahapan yang harus dilalui, karena tahapan-tahapan tersebut satu kesatuan yang akan menghasilkan sistem yang baik dan terpercaya kualitasnya. Perancangan sistem ini akan mengunakan pengembangan perangkat lunak dengan model web 
engineering. Model tersebut dipilih karena sistem aplikasi CRM ini berbasis web, sehingga pendekatan penelitian yang digunakan akan lebih tepat jika menggunakan web engineering. Karena web engineering digunakan untuk menciptakan aplikasi web yang berkualitas tinggi.

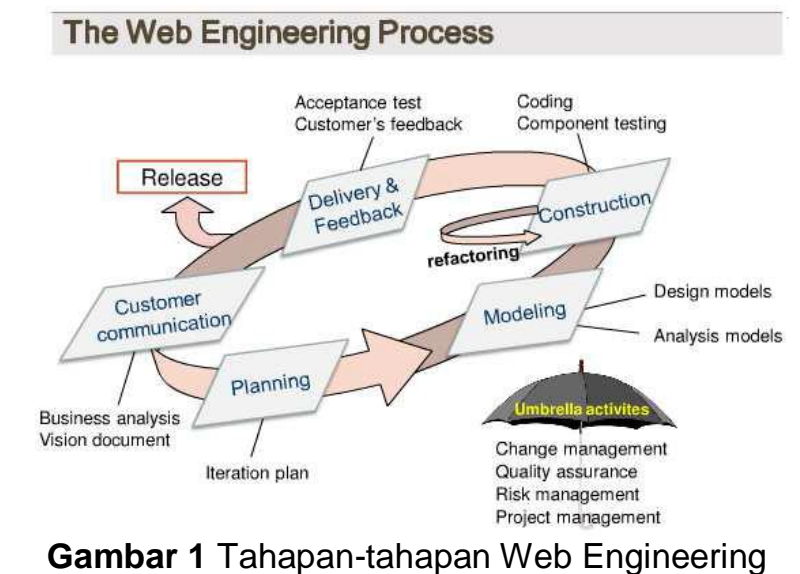

Pada Gambar 1 Tahapan-tahapan Web Engineering meliputi:

1. Costumer Communication (Komunikasi dengan Pengguna)

2. Web Engineering Planning/Perencanaan

3. Web Engineering Modelling

a. Analysis Modellingb.

b. Design Modelling

4. Web Engineering Construction

5. Web Engineering Delivery and Evaluation

\section{PEMBAHASAN}

\subsection{Analisa dan Perancangan Sistem}

\subsubsection{Perencanaan Teknis}

Mengidentifikasi perangkat lunak maupun perangkat keras apa saja yang dibutuhkan, tergantung kesepakatan pengembang. Nantinya system CRM ini akan dibuat dalam bentuk web aplikasi yang akan mampu berjalan di minimal computer yang memiliki spesifikasi pentium dan browser minimal yang support dengan html 5

\subsubsection{Kebutuhan Perangkat Keras}

a. Komputer dengan prosesor minimal intel Pentium IV $800 \mathrm{MHz}$ atau setaranya.

b. Memori RAM minimal 128MB. Untuk mendapatkan kemampuan yang lebih baik disarankan menggunakan memori RAM 256MB.

c. Kapasitas ruang hard disk minimal $512 \mathrm{MB}$

\subsubsection{Kebutuhan Perangkat Lunak}

\section{a. Sistem Operation}

Sistem operation yang dibutuhkan adalah linux atau fedora sebagai sistem servernya dan windows 7 sebagai sistem operation

b. Gammu

c. Xampp windows service 1.6.6 dalamnya terdapat Mysql yang digunakan untuk tempat penyimpanan data.

d. Perangkat lunak yang digunakan untuk membuat tampilan web dan coding php yaitu Macromedia Dreamweaver

\subsection{Modelling}

Hal utama yang dilakukan dalam tahap ini adalah memodelkan setiap aktifitas dalam sub tahapannya ke dalam bentuk diagram dengan menggunakan teknik teknik tertentu.

\subsubsection{Proses bisnis}

Alur proses bisnis pada Gambar 2 berjalan kapanpun dan dibutuhkan tenaga kusus dalam mengatasi hal tersebut. Untuk mengatasi hal tersebut user terkadang harus menjelaskan spesifikasi barang guna membantu konsumen menentukan barang mana yang akan dipilih. 
Maka untuk memaksimalkan jam pelayanan di buatlah sistem SMS CRM untuk memaksimalkan pelayanan order barang.



Gambar 2 Alur Proses Bisnis

\subsubsection{Use Case Diagram}

Merupakan permodelan untuk perilaku sistem informasi yang akan dibuat. Diagram yang menggambarkan actor, use case dan relasinya sebagai suatu urutan tindakan yang memberikan nilai terukur untuk aktor. Sebuah use case digambarkan sebagai elips horizontal dalam suatu diagram UML use case.



Gambar 3 Use Case Diagram

\subsubsection{Class Diagram}

Dalam class diagram ini terdapat yang pertama adalah diagram login dengan form username, pass, dengan tindakan masuk/login halaman,yang kedua adalah diagram barang yang dengan isianform kode_barang, nama_barang, foto, satuan, harga_beli, harga_jual, stok, dengan tindakan yang dilakukan adalah menambah barang,yang ketiga adalah diagram supplier dengan isian kode_supplier, nama_supplier, alamat, kota, provinsi, telp, fax. 


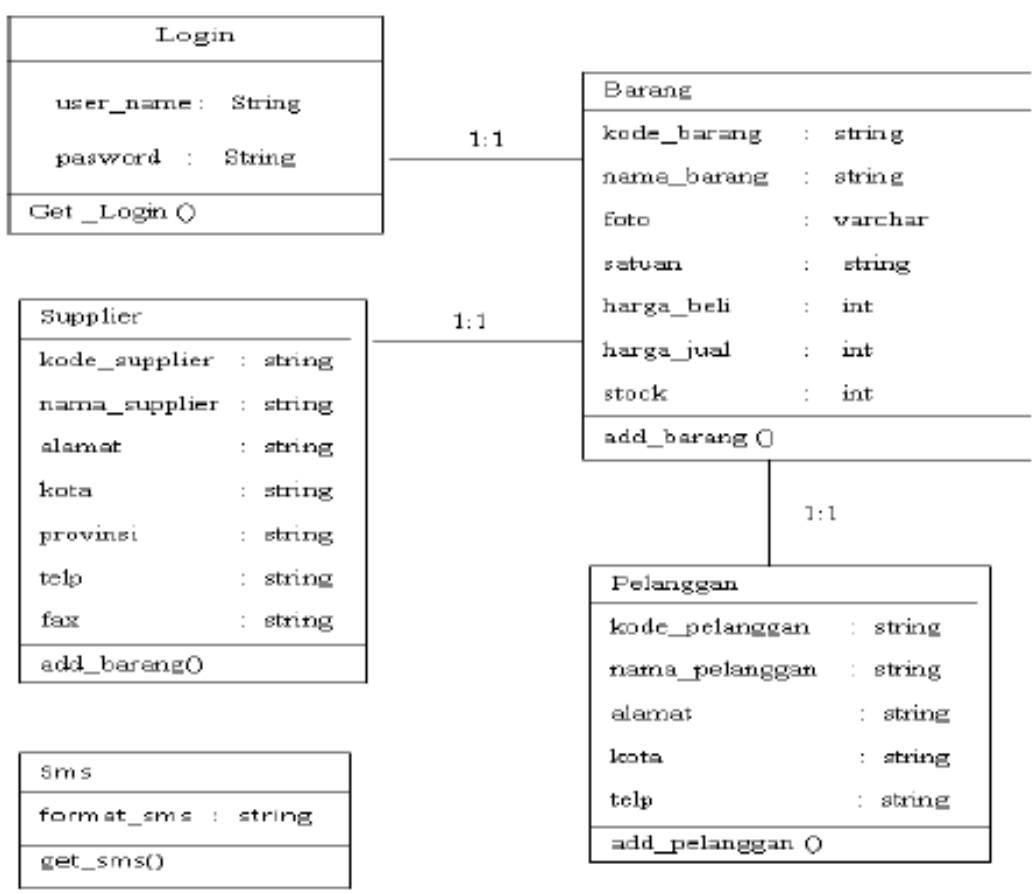

Gambar 4 Class Diagram

\subsection{Implementasi Program}

Setelah melakukan perancangan sistem terhadap aplikasi yang akan dibangun, maka tahap selanjutnya adalah mengimplementasikan hasil perancangan. Pengimplementasian aplikasi ini bertujuan untuk mengetahui sampai sejauh mana progres pengembangan berlangsung sehingga dapat dilakukan perubahan jika terdapat pemasukan dari pemakai

\subsubsection{Menu Login}

Login digunakan apabila admin ingin mengakses dan menggunakan aplikasi CRM, yang terdiri dari user dan password.

\subsubsection{Menu Daftar Barang}

Daftar barang ini berisi tentang informasi mengenai setiap produk yang telah diinputkan oleh admin, terdiri dari nama barang, foto barang, satuan, harga beli, harga jual, stok, proses. Search box produk digunakan untuk mencari produk dan informasi yang telah diinputkan. Di dalam menu daftar barang ini terdapat informasi tentang stok, yang berfungsi sebagai informasi ketika pelanggan melakukan pemesanan pada jumlah yang melebihi stok barang, maka sistem akan melakukan balasan secara otomatis kepada para pelanggan bahwa barang yang dipesan tidakcukup atau habis.

\section{KESIMPULAN}

Kesimpulan dari penelitian ini sebagai berikut :

1. Onlineshop tokofarah merasa kurangnya interaksi dengan pelanggan sehingga pihak perusahaan merasa kurang mengenal dan memahami kebutuhan pelanggannya, maka dirancanglah sebuah aplikasi CRM.

2. Pelanggan dari Onlineshop tokofarah tidak perlu menunggu layanan dari customer service untuk memperoleh informasi yang mereka butuhkan, karena mereka dapat memperolehnya melalui website kapanpun mereka butuhkan.

3. Aplikasi CRM ini dapat memudahkan pelanggan untuk mengecek seberapa jauh proses produksi yang sedang berjalanan.

4. Aplikasi ini dapat menginformasikan promosi khususnya untuk produk baru dan potongan harga produk melalui pesan broadcast yang dikirim keseluruh pelanggan. 


\section{DAFTAR PUSTAKA}

Dewantoro R A., 2007. Aradea Aplikasi Sms Gateway Dengan Koreksi Kesalahan Menggunakan Fuzzy String Matching.

Dyche. Jill. 2002. The CRM Handbook: A Business Guide to Customer Relationship Management. Boston: Addison-Wesley

Edison Tarigan,Daud. 2011. Membangun SMS Gateway Berbasis Web Dengan Codeigniter, lokomedia : Yogyakarta

Kadir, Abdul. 2008. Tuntunan Praktis Belajar Database Menggunakan MySQL. ANDI, Yogyakarta.

Nugroho,Bunafit. 2009.Membuat Website Sendiri dengan PHP-MySQL. Mediakita, Jakarta.

Tunggal, Amin W. 2008. Dasar Dasar Customer Relationship Management ( CRM ). Harvindo, Jakarta.

Wahidin. 2010. Aplikasi SMS dengan PHP untuk Orang Awam. Maxikom. Palembang. Wibisono, Gunawan. 2008. Konsep Teknologi Seluler. Informatika. Bandung 